STUDIA Z PRAWA WYZNANIOWEGO

Tom $24-2021$

DOI: https://doi.org/10.31743/spw.12690

WŁODZIMIERZ BROŃSKI*

\title{
DUCHOWNY JAKO MEDIATOR
}

Clergyman as a mediator

Streszczenie: Celem niniejszego opracowania jest omówienie problematyki udziału osoby duchownej w postępowaniu mediacyjnym jako mediatora. Mediacja jest instytucją uregulowaną $\mathrm{w}$ prawie europejskim i polskim. Jest jednak znana od początków cywilizacji, co można dostrzec w relacjach między Bogiem a ludźmi i między człowiekiem a wspólnotą. $\mathrm{W}$ artykule przedstawiono najpierw wymiar religijny mediacji i przykłady pełnienia przez osoby duchowne na przestrzeni wieków funkcji mediatora. Następnie omówiono cele postępowania mediacyjnego na tle wybranych modeli mediacji. Stwierdzono, że w każdym modelu mediacji z jednej strony ważne są potrzeby i interesy stron, a także ich relacje oraz charakter sporu determinujący cele postępowania, $z$ drugiej zaś, model mediacji nie stanowi uniwersalnej matrycy, którą można przełożyć na dany rodzaj sporu. W praktyce mediator w rozwiązywaniu jednego sporu stosuje kilka modeli postępowania mediacyjnego, dążąc do realizacji licznych celów stron sporu, co wymaga od niego posiadania wielorakich umiejętności. Zdaniem Autora, sprawowanie różnorakich funkcji religijnych powoduje, że duchowni posiadają liczne umiejętności przydatne do pełnienia funkcji mediatora. W ostatniej części opracowania dokonano analizy wymogów prawnych i specyficznych kompetencji duchownego - mediatora oraz sformułowano wnioski.

Słowa kluczowe: duchowny; mediator; cel mediacji; model mediacji

Abstract: This paper aims to discuss the issues connected with the participation of clergymen as mediators in mediation proceedings. Mediation is a legal institution regulated by European and Polish law. Yet it has been known since the beginnings

* Ks. dr hab., prof. KUL, Katedra Negocjacji i Mediacji, Wydział Prawa, Prawa Kanonicznego i Administracji, Katolicki Uniwersytet Lubelski Jana Pawła II, Al. Racławickie 14, 20-950 Lublin, e-mail: mediacja@kul.pl. ORCID 0000-0002-1303-6737. 
of civilisation, which can be observed in relations between God and people and between man and community. First, the paper presents the religious dimension of mediation and provides some examples of participation of clergymen in mediations throughout the centuries. Next, the objectives of mediation proceedings are discussed against the background of selected mediation models. It is argued that, on the one hand, in each mediation model the needs and interests of the parties are important, but equally crucial is the relationship between the parties, as well as the nature of the dispute, which determine the goals of the proceedings. On the other hand, mediation models do not constitute a universal matrix that can be mapped onto every single type of dispute. In practice, mediators use several mediation models when resolving one dispute in order achieve various goals of the parties, which requires multiple skills from mediators. In the author's opinion, the fact that clergymen fulfil a number of different religious functions makes them especially qualified to act as mediators. In the last part of the paper, the legal requirements and unique competencies of clergymen serving as mediators are analysed, and the relevant conclusions are drawn.

Key words: clergyman; mediator; purpose of mediation; model of mediation

\section{WPROWADZENIE}

Mediacja to sztuka wypracowywania porozumienia pomiędzy zwaśnionymi stronami przy udziale osoby mediatora - kreatora procesu porozumienia, który wnosi swoistą wartość dodaną (tj. własne poglądy, postawę, wartości, zaangażowanie) przy zachowaniu zasad bezstronności (art. $183^{3}$ k.p.c. ${ }^{1}$ ) i neutralności². To od ,jakości” mediatora w dużym stopniu zależy skuteczność postępowania mediacyjnego.

1 Ustawa z dnia 17 listopada 1964 r. - Kodeks postępowania cywilnego, tekst jedn. Dz. U. z 2020 r., poz. 1575 z późn. zm.

2 Neutralność nie ma charakteru normatywnego na gruncie Kodeksu postępowania cywilnego. Wyróżniono ją jednak w Standardach mediacji (standard II) obok zasady bezstronności; zob. Standardy prowadzenia mediacji i postępowania mediatora, uchwalone 26 czerwca 2006 r. przez Społeczną Radę do spraw Alternatywnych Metod Rozwiązywania Konfliktów i Sporów przy Ministrze Sprawiedliwości, https:/www.ms.gov.pl/pl/ dzialalnosc/mediacje/publikacje-akty-prawne-statystyki/download,188,6.html [dostęp: 12.06.2021]. Na temat zasad mediacji piszą m.in. Kalisz, Zienkiewicz 2009, 58-61; Dąbrowski 2019, 116-125. 
Mediacja jest uregulowana w wielu aktach normatywnych. Żaden $\mathrm{z}$ nich nie wyklucza duchownego jako mediatora. Z drugiej strony na listach mediatorów stałych brakuje osób duchownych. W związku z tym celem niniejszego opracowania jest próba omówienia kwestii związanych $\mathrm{z}$ występowaniem przez duchownego w roli mediatora w rozwiązywaniu konfliktów. W niniejszym opracowaniu zostanie najpierw przedstawiony religijny wymiar mediacji oraz podstawowe cele mediacji na tle jej wybranych modeli, a następnie podjęte zostanie zagadnienie wymogów prawnych i specyficznych kompetencji osób duchownych jako mediatorów.

\section{RELIGIJNY WYMIAR MEDIACJI}

Zainteresowanie instytucją mediacji w obecnym kształcie pojawiło się w XX w. w USA i państwach anglosaskich, gdzie dostrzeżono jej użyteczność jako uzupełniającego w stosunku do kontradyktoryjnego postępowania sądowego sposobu rozwiązywania konfliktów ${ }^{3}$. Na temat przyczyn rozwoju mediacji i implementacji zasad ADR do codziennego użytku w ramach rozwiązywania sporów na szeroką skalę istnieją dwie teorie. Pierwsza z nich upatruje podstawowego źródła rozwoju mediacji w kryzysie sądownictwa. W tym ujęciu mediacja jawi się jako odpowiedź na potrzeby społeczne w zakresie taniego, szybkiego i skutecznego rozwiązywania konfliktów. Druga teoria przywołuje założenie, że dzięki mediacji obywatele zyskują większy dostęp do wymiaru sprawiedliwości ${ }^{4}$. Skuteczność mediacji w krajach common law wpłynęła na ożywienie zainteresowania mediacją w Europie i w Polsce. Pierwsze regulacje prawne dotyczące instytucji mediacji wprowadzone zostały w Polsce w 1991 r. w ustawie o rozwiązywaniu sporów zbiorowych ${ }^{5}$. W 1995 r. powstał Zespół ds. Wpro-

3 Do obecnego kształtu aktualnych alternatywnych metod rozwiązywania konfliktów przyczyniły się związki zawodowe, które poprzez domaganie się praw z zakresu prawa pracy w 1926 r. doprowadziły do uchwalenia Kolejowej Ustawy Pracowniczej (Railway Labor Act), która doprowadziła m.in. do stworzenia Krajowej Rady ds. Mediacji. W 1936 r. jej przepisami objęto również przemysł lotniczy. Zob. Barrett, Barrett 2004, 74-75.

4 Kordasiewicz 2009, 44.

5 Ustawa z dnia 23 maja 1991 r. o rozwiązywaniu sporów zbiorowych, tekst jedn. Dz. U. z 2020 r., poz. 123. 
wadzania Mediacji w Polsce. W 2001 r. mediacja została wprowadzona do postępowania w sprawach nieletnich ${ }^{6}$, a z dniem 1 lipca 2003 r. - do Kodeksu postępowania karnego (art. 23a)7. W 2004 r. postępowanie mediacyjne i koncyliacyjne wprowadzono również do postępowania sądowo-administracyjnego ${ }^{8}$, a od 10 grudnia 2005 r. mediacją objęto sprawy cywilne, w tym rodzinne.

Instytucja mediacji uregulowana $\mathrm{w}$ prawie polskim ma swoje teologiczne podstawy oraz bogaty religijny i duchowy rodowód ${ }^{9}$. Człowiek jest bowiem istotą społeczną, a konflikty stanowią naturalny i nieunikniony element relacji międzyludzkich zarówno w państwie, jak i w Kościele, który został ukonstytuowany na tym świecie jako społeczność (kan. 204 $\S 2 \mathrm{KPK})^{10}$. Właściwym narzędziem ich rozwiązywania jest dialog rozumiany jako „wkroczenie na tę drogę, na której wzajemnie stosunki między ludźmi układają się według zasad roztropności i szczerości i przynosi korzyści, jakie daje doświadczenie i mądrość, które wszystkich nakłaniają do skupienia uwagi na najcenniejszych wyższych wartościach"11. Przykazanie miłości wymaga, aby każdy konflikt był rozwiązywany w duchu pojednania i przebaczenia. Znaczenie ma nade wszystko to, aby została przywrócona współpraca między członkami Kościoła, a nie to, by zwyciężył ten, kto ma rację $\mathrm{w}$ sporze ${ }^{12}$. Zatem podstawowe cele mediacji, jakimi są pojednanie stron i odbudowa relacji, pozostają w zgodności z zasadami

6 Ustawa z dnia 26 października 1982 r. o postępowaniu w sprawach nieletnich, tekst jedn. Dz. U. z 2018 r., poz. 969.

7 Ustawa z dnia 6 czerwca 1997 r. - Kodeks postępowania karnego, tekst jedn. Dz. U. z 2021 r., poz. 534 z późn. zm.

8 Ustawa z dnia 30 sierpnia 2002 r. - Prawo o postępowaniu przed sądami administracyjnymi, tekst jedn. Dz. U. z 2019 r., poz. 2325 z późn. zm.

9 Giba 2000, 1703.

10 Codex Iuris Canonici auctoritate Ioannis Pauli PP. promulgatus (25.01.1983), AAS 75 (1983), cz. II, s. 1-317; tekst polski: Kodeks Prawa Kanonicznego. Przekład polski zatwierdzony przez Konferencję Episkopatu, Poznań: Pallotinum 1984.

11 Paulus PP. VI, Litterae Encyclicae Ecclesiam Suam (6.08.1964), AAS 56 (1964), s. 609-659; tekst polski: Paweł VI, Encyklika o drogach, którymi Kościół Katolicki powinien kroczyć $w$ dobie obecnej przy petnieniu swojej misji Ecclesiam suam, Wrocław 2006 (nr 106).

12 Grocholewski 2002, 79. 
chrześcijańskimi i prawem kanonicznym ${ }^{13}$. Sama idea rozjemstwa jest „ściśle zespolona z istotą chrześcijaństwa”. Wypływa z miłości i zgody, które stanowią fundamentalne zasady w Kościele Chrystusowym ${ }^{14}$.

Chociaż w Piśmie Świętym nie pojawia się expressis verbis słowo „mediacja", to instytucja ta istniała od początku cywilizacji między Bogiem a społecznością i między człowiekiem a wspólnotą ${ }^{15}$. W czasach biblijnych w społecznościach żydowskich była stosowana przez przywódców religijnych i politycznych. Tradycja ta została przejęta przez wspólnoty chrześcijańskie $^{16}$. Dla chrześcijan najwyższym mediatorem jest Jezus Chrystus, który w Piśmie Świętym jest nazywany „Pośrednikiem”.

Zachęty do rozwiązywania sporów w drodze polubownej można się dopatrzyć we fragmencie Ewangelii św. Mateusza mówiącej o upomnieniu braterskim (Mt 18,15-17). Z nakazu Ewangelii wynika, że najpierw powinno dojść do dialogu bezpośrednio pomiędzy stronami. W przypadku braku efektów rozmowy, należy wziąć ze sobą ,jednego albo dwóch, aby na słowie dwóch lub trzech świadków oparła się cała sprawa”. Jeżeli i ta próba pogodzenia nie zakończy się pojednaniem, strony powinny poddać spór pod rozstrzygnięcie przedstawicieli danej społeczności (Pwt 1, 9-18; 16, $18-20 ; 17,8-11)^{17}$. Podstawę mediacji stanowi zatem prawo ewangeliczne oparte na miłości, a zachęta do korzystania z tego sposobu rozwiązywania sporów wynika z chrześcijańskiego ducha zgody ${ }^{18}$.

Co najmniej pośrednie zachęty do stosowania mediacji odnaleźć można również $\mathrm{w}$ dokumentach soborowych, a także w nauczaniu papieży i dziełach pisarzy chrześcijańskich; wszędzie tam, gdzie jest mowa o pokoju, pojednaniu, sprawiedliwości i dialogu ${ }^{19}$. Podkreśla się, że rozwiązywanie konfliktów ma przede wszystkim swoje źródło w dialogu prowadzonym w duchu miłości. Dialog zakłada określony stosunek do drugiej

13 Roseman 2013, 145.

14 Myrcha 1948, 14.

15 Mediacja istniała we wszystkich kulturach świata i była stosowana - poza chrześcijaństwem - w judaizmie, hinduizmie, buddyzmie, islamie, konfucjonizmie. Zob. Kordasiewicz 2009, 31-50; Moore 2009, 35.

16 Zob. Giba 2000, 1701-1703.

17 Romanko 2016, 20.

18 Pawluk 2009, 30.

19 Szerzej na ten temat pisze Romanko 2016, 22-35. 
osoby i do posiadanej przez siebie i innych prawdy, wyznacza sposób postępowania i współdziałania, prowadzi do spotkania i porozumienia. Podstawowymi elementami dialogu są: rzeczywistość międzyludzkiego kontaktu, wzajemna życzliwość, wspólne poszukiwanie wartości i szczególna atmosfera, w jakiej dokonuje się spotkanie międzyludzkie będące istotą dialogu. Dialog to gotowość na wspólne poszukiwanie prawdy ${ }^{20}$. Tak rozumiany dialog, w którego centrum jest osoba ludzka i poszanowanie jej praw i godności, konstytuuje istotę instytucji mediacji i jest podstawą postępowania mediacyjnego.

Kościół pojmując rolę Chrystusa jako Pośrednika i najwyższego mediatora, a dialog jako ,w pewnym sensie środek, a nade wszystko sposób wypełniania jego działalności w świecie współczesnym"21, zalecał pozasądowe sposoby rozwiązywania sporów od początku swego istnienia ${ }^{22}$. Przykładowo św. Augustyn w sytuacjach spornych wysłuchiwał argumentów skłóconych stron, a następnie rozwiązywał określony konflikt ${ }^{23}$. Świeccy pomagali biskupowi w rozwiązywaniu trudnych spraw ${ }^{24}$. W IV w. wprowadzono nawet specjalną instytucję episcopalis audientia, której istotą było rozwiązywanie konfliktów przez biskupów w społeczności kościelnej25. Biskupi cieszyli się bowiem zaufaniem wiernych oraz posiadali potrzebne umiejętności i doświadczenie życiowe ${ }^{26}$. Funkcję mediatora pomiędzy burmistrzem a biskupem Asyżu pełnił św. Franciszek z Asyżu oraz Bracia Mniejsi w XIII-wiecznych Włoszech, wykorzystując pieśń jako technikę mediacji. Z pełnienia funkcji mediatora słynął również papież Grzegorz IX, który mediował w sporze pomiędzy Cesarzem Rzymskim i Ligą

20 Zob. Nagy 1982, 155-158

21 Ioannes Paulus PP. II, Adhortatio apostolica Reconciliatio et Paenitentia (2.12.1984), AAS 77 (1985), s. 185-275; tekst polski: Jan Paweł II, Adhortacja apostolska o pojednaniu i pokucie Reconciliatio et Paenitentia, Wrocław 1984 ( $\mathrm{nr} 25)$.

22 Moore 2009, 35. W jego ocenie Kościół Katolicki w Europie zachodniej i Kościół prawosławny we wschodnim rejonie Morza Śródziemnego były najważniejszymi ośrodkami mediacji w zachodnim społeczeństwie. Duchowni prowadzili mediację w sporach rodzinnych, karnych i dyplomatycznych.

23 Brown 1993, 192.

24 Tamże, 226.

25 Tamże, 194.

26 Myrcha 1948, 15. 
Lombardzką. Takiego zadania podejmowali się również Benedykt XV, Paweł VI i Jan Paweł II ${ }^{27}$.

Mediacja ma zatem religijny wymiar. Była i jest podstawową metodą rozwiązywania sporów zarówno we wspólnotach religijnych, jak i społecznościach świeckich.

\section{CELE POSTĘPOWANIA MEDIACYJNEGO \\ NA TLE WYBRANYCH MODELI MEDIACJI}

Analiza treści przepisów prawa, w tym również sama istota mediacji, pozwala sformułować wniosek, iż podstawowym celem postępowania mediacyjnego jest umożliwienie stronom sporu zawarcie ugody uchylającej spór, która w sposób maksymalny realizuje interesy stron i wyklucza konieczność postępowania przed sądem ${ }^{28}$. Skuteczność postępowania mediacyjnego zależy jednak zazwyczaj od realizacji wielu szczegółowych celów stron sporu, których realizacja warunkuje zawarcie ugody. Cele mediacji niejednokrotnie wykraczają zatem poza cele samej ugody. Konieczne jest szerokie spojrzenie na spór i jego źródła, na obecne i przyszłe relacje pomiędzy stronami sporu oraz na oczekiwania stron, aby wypracować sposoby komunikacji, które w przyszłości pozwolą zapobiec konfliktom lub zarządzać nimi. Zwrócenie uwagi na owe aspekty może wpłynąć na trwałość ugody, decydując m.in. o sile moralnego zobowiązania do realizacji postanowień już zawartej ugody. Zadaniem mediatora jest przeto pomoc stronom $\mathrm{w}$ doprecyzowaniu ich celów i takie prowadzenie postępowania mediacyjnego, aby te cele w możliwie najlepszy sposób urzeczywistnić. Tym właśnie, jak i przyjętym modelem postępowania mediacyjnego i wynikającą z niego funkcją mediatora, w głównej mierze zdeterminowany jest kształt i przebieg mediacji, co czyni z niej postępowanie oparte na interesach stron i próbie ich pogodzenia ${ }^{29}$.

W doktrynie najszerszy i uporządkowany podział celów postępowania mediacyjnego przedstawili A. Kalisz i A. Zienkiewicz. Wyróżniają cel

\footnotetext{
27 Zob. Giba 2000, 1695-1701.

28 Morek 2009, 18.

29 Baruch Bush, Folger 2012, 12.
} 
główny w postaci ugody i cele szczegółowe, dzieląc je na nadrzędne i podrzędne ${ }^{30}$. Do nadrzędnych zaliczają cele $\mathrm{w}$ wymiarze personalnym (osobistym), interpersonalnym i społecznym, a do podrzędnych cele o charakterze komunikacyjnym, psychologicznym i negocjacyjno-informacyjnym. Cele nadrzędne w wymiarze personalnym realizowane są poprzez procesy samopoznawania, samodoskonalenia i wewnętrznego wzrostu moralnego, które powinny zachodzić w trakcie dyskursu mediacyjnego i zmierzać do kształtowania postawy naturalnego dążenia do pokojowego, kompromisowego i opartego na akceptowalnych wartościach współistnienia społecznego ${ }^{31}$. Cele $\mathrm{w}$ wymiarze interpersonalnym koncentrują się na przyczynach konfliktu, których diagnoza i zrozumienie przez obie strony sporu skutkuje wygaszeniem konfliktu i daje podstawę do przywrócenia i podtrzymywania poprawnej komunikacji między stronami oraz pozytywnych relacji. Natomiast cele mediacji w wymiarze społecznym utożsamia się nade wszystko $\mathrm{z}$ uzasadnieniem dla uregulowania tej instytucji $\mathrm{w}$ taki sposób, aby zapobiegać nadmiernemu obciążeniu sądów, ułatwić obywatelom dostęp do wymiaru sprawiedliwości i promować kulturę prawną opartą na polubownym rozwiązywaniu sporów ${ }^{32}$. Cele podrzędne dotyczą uczciwej i prawidłowej komunikacji pomiędzy stronami, której podstawą jest otwartość i współpraca w poszukiwaniu płaszczyzny porozumienia i formułowaniu rozwiązań możliwych do zaakceptowania poprzez wszystkich uczestników postępowania mediacyjnego ${ }^{33}$. Cele szczegółowe warunkują możliwość zawarcia ostatecznego porozumienia i nie powinny podlegać hierarchizacji z punktu widzenia ich ważności.

Cele mediacji są ściśle skorelowane z modelami postępowania mediacyjnego, czyli sposobami jego prowadzenia i zarazem funkcją, jaką spełnia w nim mediator. Subiektywne cele stron sporu oraz cele, które w opinii

30 Zob. Kalisz, Zienkiewicz 2009, 43-45.

31 Szerzej na temat etapów rozwoju osobowego w związku z mediacją pisze Seul 1999-2000, 143-157.

32 Zdaniem M. Dąbrowskiego cele w wymiarze społecznym nie mają charakteru nadrzędnego ani dla stron sporu, ani dla mediatora. „Mogą jedynie stanowić wypadkową pozytywnie przeprowadzonej mediacji, będąc rezultatem zaspokojenia interesów i potrzeb stron sporu w formie ugody, a tym samym zapobiegając konieczności prowadzenia postępowania przed sądem”. Dąbrowski 2019, 58.

33 Kalisz, Zienkiewicz 2014, 44-45. 
mediatora muszą zostać zrealizowane, aby osiągnąć porozumienie, a także charakter danego sporu decydują o tym, który z modeli postępowania mediacyjnego zostanie wybrany dla rozwiązania zaistniałego konfliktu ${ }^{34}$.

W podstawowej typologii mediacji wyróżnia się mediację facylitatywną, określaną mianem klasycznej i ewaluatywną, czyli ocenną. Model facylitatywny zakłada możliwie najmniejszą interwencję mediatora w spór oraz zdolność stron z pomocą odpowiednio przygotowanego mediatora do samodzielnego wypracowania obopólnie satysfakcjonującego rozwiązania. Takie rozwiązanie wywodzące się od stron sporu powinno w największym możliwym stopniu realizować ich potrzeby i interesy, a także wpływać na trwałość zawartego porozumienia. W modelu tym mediator nie proponuje stronom sporu żadnych rozwiązań, nie dokonuje żadnej oceny podnoszonych przez strony argumentów, co oczywiście nie wyklucza dyskusji na temat ich realności. Nie występuje również w roli eksperta w odniesieniu do merytorycznej warstwy sporu. Ma wyłącznie stworzyć warunki do zdefiniowania problemów i twórczego ich rozwiązania. W tym celu koncentruje uwagę stron sporu nie na stanowiskach, ale na ich potrzebach i interesach ${ }^{35}$ oraz wspomaga i usprawnia proces komunikacji, stosując techniki służące odblokowaniu, rozwinięciu i porządkowaniu komunikacji między stronami, redukowaniu negatywnych emocji i pomocy w znalezieniu i wyartykułowaniu przez nie propozycji rozwiązania sporu ${ }^{36}$. Według B. Mayera funkcję mediatora w modelu facylitatywnym można sprowadzić do czterech celów. Po pierwsze jego zadaniem jest umożliwienie interakcji stron bez formułowania propozycji możliwych rozwiązań. Po drugie mediator powinien pomagać stronom w odejściu od modelu współzawodnictwa na rzecz współpracy, tak by uczestnicy postępowania mediacyjnego samodzielnie dokonywali oceny problemów i możliwych konsekwencji i generowali propozycje rozwiązań. Po trzecie ma on wspierać proces komunikacji służący poszukiwaniu rozwiązań. I w końcu po czwarte, tak ma wspierać strony, aby uświadomiły sobie potrzeby nie tylko własne, ale i drugiej strony i uwzględniły je w treści porozumienia ${ }^{37}$.

34 Aleksander 2009, 12.

35 Stitt 2004, 4.

36 Zienkiewicz 2007, 174. Zob. Cooley 2006, 32.

37 Mayer 2004, 32-33. 
Przeciwieństwem mediacji facylitatywnej jest model ewaluatywny. W modelu tym do podstawowych zadań mediatora należy ocena charakteru sporu i podnoszonych argumentów, stanowisk formułowanych przez strony z możliwością przedstawienia propozycji rozwiązania problemu. Wprawdzie mediator nie posiada prawa do narzucania stronom sporu wiążących rozwiązań - kompetencje co do sposobu rozwiązania sporu pozostają w gestii samych stron - jest jednak ekspertem merytorycznym i pełni aktywną rolę w poszukiwaniu ostatecznego rozwiązania. Według L. Riskina celem mediatora w modelu mediacji ewaluatywnej jest ocena słabych i silnych stron przedstawianych przez strony propozycji, możliwość ich przeformułowania, a także przedstawienia własnych pomysłów rozwiązań będących z punktu widzenia mediatora najbardziej obiektywnymi, w tym również możliwych rozstrzygnięć sporu przed sądem ${ }^{38}$. W doktrynie podkreśla się, że szereg zachowań mediatora może skutkować transformacją jego roli w kierunku podmiotu rozstrzygającego spór ${ }^{39}$. Poza tym wydawane przez niego opinie lub formułowane propozycje rozwiązań mogą być obarczone błędem, co może wynikać nie tyle z braku dobrej woli, co $\mathrm{z}$ niedostatków odpowiedniego przygotowania, stopnia posiadanej wiedzy bądź niewłaściwego zrozumienia toczącego się sporu. To wszystko może doprowadzić do podejmowania błędnych decyzji, a nawet eskalacji sporu w sytuacji gdy nie zostanie wzięty pod uwagę na przykład interes jednej ze stron. Mediacja w modelu ewaluatywnym jest bardziej rozstrzyganiem niż rozwiązywaniem sporu, a mediator - bardziej arbitrem wydającym decyzje, które mają niewiążący charakter ${ }^{40}$. Oczywiście model ten ma też wiele zalet. Sprawdza się przede wszystkim w sytuacjach, kiedy strony nie są w stanie samodzielnie wypracować rozwiązań i oczekują pomocy od bezstronnego mediatora - pod warunkiem że mediator ten posiada odpowiednią wiedzę, doświadczenie i autorytet ${ }^{41}$.

W doktrynie wymienia się też szereg innych modeli mediacyjnych, w tym np. model oparty na interesach stron, transformatywny, narratywny czy też humanistyczny. Pierwszy z nich jest zbliżony do mediacji

\footnotetext{
38 Zob. Riskin 1996, 29-32.

39 Stulberg 1997, 996.

40 Zob. Lowry 2004, 76; Stitt 2004, 4.

41 Dąbrowski 2019, 63.
} 
facylitatywnej. Bazuje na modelu negocjacji problemowych zaproponowanym przez R. Fishera i W. Urye'go. Pozostałe modele znajdują zastosowanie w wielu rodzajach sporów, a zwłaszcza tam, gdzie głównym celem postępowania mediacyjnego jest naprawienie relacji pomiędzy stronami. Naczelną wartością tychże modeli jest dialog, a rozwiązanie sporu w formie ugody jest wtórne ${ }^{42}$.

W każdym modelu mediacji, $\mathrm{z}$ jednej strony ważne są potrzeby $\mathrm{i}$ interesy stron, a także ich relacje oraz charakter sporu determinujący cele postępowania, z drugiej zaś należy pamiętać, że model mediacji nie stanowi uniwersalnej matrycy, którą można przełożyć na dany rodzaj sporu. W praktyce mediator w rozwiązywaniu jednego sporu stosuje kilka modeli postępowania mediacyjnego dążąc do realizacji licznych celów stron sporu, co wymaga od niego posiadania wielorakich umiejętności.

\section{WYMOGI PRAWNE I SPECYFICZNE KOMPETENCJE OSÓB DUCHOWNYCH JAKO MEDIATORÓW}

Sąd kierując strony sporu do mediacji odsyła je do osoby mediatora, który przygotowuje i kieruje postępowaniem mediacyjnym. Od „jakości” mediatora $\mathrm{w}$ dużej mierze zależą efekty postępowania mediacyjnego. To zaś wiąże się bezpośrednio z tym, kto może być mediatorem, odpowiednim przygotowaniem merytorycznym mediatora, weryfikacją jego umiejętności, gwarancjami odnoszącymi się do sprawowanej przez niego funkcji i odpowiedzialnością. Przepisy prawa powinny zatem chociaż w minimalnym stopniu to określać ${ }^{43}$. Jest o tym mowa między innymi w rekomendacji Rady Europy Nr R (98) 144, rekomendacji Rady Euro-

42 Tamże, 61, 63-64.

43 Dąbrowski 2019, 79.

44 Rekomendacja Komitetu Ministrów Rady Europy Nr R (98) 1 w sprawie mediacji rodzinnej oraz Memorandum Wyjaśniające z dnia 21 stycznia 1998 r. (Recommendation No. $R$ (98) 1 on family mediation), https://www.coe.int/en/web/cdcj/recommendations--resolutions-guidelines [dostęp: 24.05.2021]. Podkreślono w niej, że państwa członkowskie powinny stworzyć mechanizmy wyboru i kwalifikacji mediatorów oraz określić standardy, jakie powinni oni spełniać. 
py $\mathrm{Nr}$ R (2002) $10^{45}$, w art. 4 dyrektywy 2008/52/WE ${ }^{46}$, a także w treści uzasadnienia do zarządzenia Ministra Sprawiedliwości z dnia 1 sierpnia 2005 r. ${ }^{47} \mathrm{i}$ w uzasadnieniu do nowelizacji Kodeksu postępowania cywilnego z dnia 10 września 2015 r., w którym stwierdza się, że „ze względu na to, że sądy kierują strony do mediacji istnieje obowiązek państwa do zagwarantowania stronom najwyższej jakości usług świadczonych przez profesjonalnych mediatorów" ${ }^{48}$.

W prawie polskim mediatorem może być osoba fizyczna posiadająca pełną zdolność do czynności prawnych i pełnię praw publicznych (art. $183^{2} \S 1$ k.p.c.) oraz bezstronna przy prowadzeniu mediacji (art. $183^{3}$ $\S 1$ k.p.c.). Polskie przepisy regulujące instytucję mediatora w sprawach

45 Rekomendacja Komitetu Ministrów Rady Europy Nr R (2002) 10 w sprawie mediacji w sprawach cywilnych z dnia 18 września 2002 r., (Recommendation $R(2002) 10$ on mediation in civil matters), http://ec.europa.eu/civiljustice/adr/adr_ec_code_conduct pl.pdf [dostęp: 11.08.2018]. Zwrócono w niej uwagę na potrzebę szerszego uregulowania statusu mediatora.

46 Dyrektywa Parlamentu Europejskiego i Rady 2008/52/WE z dnia 21 maja 2008 r. w sprawie niektórych aspektów mediacji w sprawach cywilnych i handlowych, Dz. Urz. UE L 136 z 24.05.2008 r. Zgodnie z brzmieniem powołanego przepisu państwa członkowskie powinny zagwarantować stronom skuteczne, bezstronne i kompetentne prowadzenie postępowania mediacyjnego.

47 Zarządzenie Ministra Sprawiedliwości z dnia 1 sierpnia 2005 r. w sprawie powołania Społecznej Rady do spraw Alternatywnych Metod Rozwiązywania Konfliktów i Sporów przy Ministrze Sprawiedliwości, Dz. Urz. MS z 2005 r. Nr 5, poz. 19. W uzasadnieniu do tego zarządzenia czytamy: „osoby, którym powierzono prowadzenie ADR w ramach postępowania sądowego, muszą posiadać dowód kwalifikacji, szkoleń lub odpowiedniego doświadczenia, które za każdym razem są oceniane przez sąd, lub posiadać uznawaną urzędową akredytację" (s. 7). Należy zauważyć, że w uzasadnieniu projektu zmian w Kodeksie postępowania cywilnego z 2005 r. stwierdzono: „Umiejętność prowadzenia mediacji jest w dużej mierze kwestią osobowości mediatora. Dlatego też, aby ułatwić stronom możliwość prowadzenia mediacji nie przewiduje się żadnych wymogów co do wykształcenia mediatora" (Druk Sejmowy nr 3213 z 20.08.2004 r., pkt V, s. 3, http://orka.sejm.gov.pl/Druki4ka.nsf/(\$vAllByUnid)/305361F62F5C0C17C 1256F000038DD87/\$file/3213.pdf). Doszło zatem do weryfikacji wyrażonego tu poglądu, co jest aktualnie widoczne chociażby w przepisach prawa regulujących instytucję mediacji.

48 Uzasadnienie projektu ustawy o zmianie ustawy - Kodeks postępowania cywilnego oraz niektórych innych ustaw w związku ze wspieraniem polubownych metod rozwiązywania sporów, 22 maja 2015 r., Druk Sejmowy nr 3432, s. 14. 
cywilnych, gospodarczych, rodzinnych, administracyjnych, karnych, nieletnich nie wykluczają osoby duchownej jako mediatora. W zależności od obszaru mediacji osoba duchowna musi spełniać wszystkie wymogi stawiane mediatorowi przepisami prawa ${ }^{49}$. Nie może jednak w ramach postępowania mediacyjnego - mając na uwadze art. 25 ust. 3 Konstytucji Rzeczypospolitej Polskiej ${ }^{50}$, zgodnie z którym ,[... s stosunki między państwem a kościołami i innymi związkami wyznaniowymi są kształtowane na zasadach poszanowania ich autonomii oraz wzajemnej niezależności każdego w swoim zakresie, jak również współdziałania dla dobra człowieka i dobra wspólnego" - realizować działalności duszpasterskiej.

Pośrednie gwarancje dla prowadzenia działalności mediacyjnej przez wszystkie kościoły i inne związki wyznaniowe w Polsce można odnaleźć w ustawie z dnia 17 maja 1989 r. o gwarancjach wolności sumienia i wyznania ${ }^{51}$. Zgodnie $\mathrm{z}$ jej brzmieniem korzystanie przez kościoły $i$ inne związki ze swobody działania, w tym w obszarze prowadzenia mediacji, odbywa się zgodnie z ogólnie przyjętymi przepisami, chyba że ustawy stanowią inaczej (art. 27 ust. 2). Natomiast w myśl art. 12 ust. 1: „Duchowni oraz osoby zakonne kościołów i innych związków wyznaniowych, ustanowione według przepisów prawa wewnętrznego kościoła lub innego związku wyznaniowego, korzystają z praw i podlegają obowiązkom na równi z innymi obywatelami we wszystkich dziedzinach życia państwowego, politycznego, gospodarczego, społecznego i kulturalnego. Są oni w ramach obowiązujących przepisów ustaw zwolnieni z obowiązków niemożliwych do pogodzenia z pełnieniem funkcji duchownego lub osoby zakonnej”. Natomiast szczególnych gwarancji dla Kościoła Katolickiego i należących do niego osób duchownych

49 Przykładowo, kto może być mediatorem w sprawach nieletnich reguluje rozporządzenie Ministra Sprawiedliwości z dnia 18 maja 2001 r. w sprawie postępowania mediacyjnego sprawach nieletnich, Dz. U. z 2001 r. Nr 56, poz. 591 z późn. zm., a w sprawach karnych - rozporządzenie Ministra Sprawiedliwości z dnia 7 maja 2015 r. w sprawie postępowania mediacyjnego w sprawach karnych, Dz. U. z 2015 r., poz. 716.

50 Konstytucja Rzeczypospolitej Polskiej z dnia 2 kwietnia 1997 r., Dz.U. z 1997 r. Nr 78 , poz. 483 z późn. zm.

51 Ustawa z dnia 17 maja 1989 r. o gwarancjach wolności sumienia i wyznania, tekst jedn. Dz. U. z 2017 r., poz. 1153. 
w działalności mediacyjnej należy upatrywać w konkordacie podpisanym w dniu 28 lipca 1993 r. $^{52}$

Mając na uwadze cele mediacji i opisane powyżej modele postępowania mediacyjnego należy stwierdzić, że duchowni - mediatorzy raczej nie powinni prowadzić mediacji w modelu ewaluatywnym. Ich rolą jest nade wszystko jednanie ludzi ze sobą i doprowadzenie skłóconych stron do wzajemnego dialogu, budowanie wspólnoty, naprawianie międzyludzkich relacji, nie zaś bycie ekspertem w dziedzinie np. gospodarki, finansów itd., gdyż nie jest to misją kapłana. Powinni z jednej strony bezwzględnie szanować autonomię porządku doczesnego, z drugiej zaś być ojcem, bratem, przyjacielem, duchowym przywódcą i liderem otwartym na ludzi i pomagającym im ,szukać dobra tam, gdzie nie potrafią go sami dostrzec" ${ }^{33}$. Ze względu na swoje wykształcenie (filozofia i teologia z elementami pedagogiki, psychologii, socjologii, katolickiej nauki społecznej, prawa kanonicznego) i pełnioną w Kościele misję, wydaje się, że umieją aktywnie słuchać i są w stanie wykazywać się elastycznością, kreatywnością i wyobraźnią niezbędną do pomocy stronom w rozwiązywaniu ich sporów w mediacji facylitatywnej ${ }^{54}$. Będą też prawdopodobnie w stanie dostrzec merytoryczne treści przekazywane przez uczestników sporu, zidentyfikować kwestie sporne, które należy przedyskutować, pomóc dostrzec stronom jako bliźnim swoje wzajemne interesy i zachęcić do współpracy, odpowiednio zorganizować rozmowę, unikać emocjonalnego zaangażowania w spór, a kierując się określonymi zasadami i wartościami potencjalnie pomagać stronom w osiąganiu celów szczegółowych trwającej mediacji, jak i zawrzeć ugodę uchylającą spór.

Duchowni - mediatorzy są reprezentantami wymiaru etycznego i uwidaczniają sobą określony system wartości. Powinni zatem szanować odmienne systemy wartości u stron sporu poszukując równocześnie uniwersalnych wartości wspólnych dla wszystkich uczestników postępowania mediacyjnego, które staną się fundamentem dialogu, pozwolą stronom

52 Konkordat między Stolicą Apostolską i Rzecząpospolitą Polską podpisany w Warszawie dnia 28 lipca 1993 r., Dz. U. z 1998 r. Nr 51, poz. 318. Zob. Zarzycki 2007, 374-383.

53 Tak udział w mediacji argumentował bp Marian Florczyk. Zob. Burgoński 2009, 139-158.

54 Brak badań empirycznych pozwala w niniejszym opracowaniu jedynie na ukazanie tendencji w zachowaniu, które prawdopodobnie przejawia większość duchownych. 
wentylować duże emocje oraz sprzyjać rzeczowej rozmowie i trwałemu porozumieniu ${ }^{55}$. Te wspólne wartości mają dwa źródła: powszechnie podzielane wartości występujące w społeczeństwie jako całości, w tym np. równość i sprawiedliwość, oraz wartości religijne, w tym miłość bliźniego, wiara w ostateczne rozliczenie i sens osobistego poświęcenia dla dobra innych. Ważne jest, aby zauważyć, że wartości religijne i inne powszechnie podzielane wartości nie wykluczają się wzajemnie. Wydaje się również, że duchownym - mediatorom powinno być łatwiej niż mediatorom świeckim powstrzymać się od oceniania ludzi i dostrzegać podczas mediacji u uczestników tęsknotę za wzajemnym szacunkiem, równością, bezpieczeństwem i innymi tego typu niematerialnymi wartościami (interesami), które w praktyce są czasami ważniejsze niż zadośćuczynienie materialne.

Pomostem dla wzajemnego zrozumienia w mediacji może być wyznawana religia. Duchowni jako przedstawiciele kościołów lub innych związków wyznaniowych mają prawo do tego, aby próbować za zgodą stron przedyskutować z nimi religijne aspekty sporu. Ta religijna refleksja powinna się jednak koncentrować na religii wyznawanej przez strony sporu, a nie duchownego - mediatora. Chociaż nie gwarantuje ona wynegocjowania ugody, to jednak sprzyja wzajemnemu zrozumieniu, które jest celem mediacji. Ponadto tam gdzie nie ma wspólnej płaszczyzny porozumienia między stronami, co prowadzi do sytuacji, w której obie strony przegrywają, dostrzeżenie i akceptacja wartości religijnych może ujawnić nieprzewidzianą wcześniej płaszczyznę porozumienia, dostarczyć motywacji do poszukiwania rozwiązania, zmienić postawy stron i pomóc w przeformułowaniu trwającego sporu z indywidualnego zysku lub straty na przebaczenie dla dobra wspólnego ${ }^{56}$.

Umiejętności duchownego - mediatora mogą być bardzo pomocne w rozwiązywaniu niektórych kategorii sporów i osób. Przykładowo

55 Praktyka mediacyjna z udziałem duchownych - mediatorów w przyszłości zweryfikuje, czy będą potrafili szanować odmienne wartości stron sporu i poszukiwać uniwersalnych wspólnych wartości uczestników postępowania mediacyjnego.

56 Giba 2000, 1699. Mając na uwadze religijny i duchowy wymiar mediacji, przykładowo Christian Conciliation Service pomaga chrześcijanom reagować na konflikty w sposób zgodny z Biblią. Według CCS celem mediacji jest uwielbienie Boga przez miłość bliźniego i pomoc spierającym się stronom w zmianie postawy i zachowania, aby uniknąć podobnych konfliktów w przyszłości. Tamże, 1703. 
załóżmy, że sąd skierował do mediacji sprawę o rozwód z pozwu męża. Podczas rozmowy na osobności mąż określił siebie jako osobę wierzącą i praktykującą. Jako przyczynę rozpadu małżeństwa wskazał ultrareligijność żony, która jego zdaniem rozmawia w domu tylko językiem Biblii i zmusza do radykalnych postów. Zdaniem męża wpływa to niekorzystnie na zdrowie dziecka, a jemu stawia coraz wyższe, wręcz niedoścignione wymagania dotyczące praktyk religijnych, stawiając siebie jako wzór. Rozmówca twierdził, że przez lata starał się zmieniać, aby sprostać oczekiwaniom żony. Jednakże zniechęcony rosnącymi wymaganiami, których spełnić nie mógł, ostatecznie przyjął postawę konfrontacyjną i wręcz antyreligijną. Z powodu nadzwyczajnej religijności żony i coraz wyżej stawianych mu wymogów, w małżeństwie czuł się osobą gorszą, niedocenioną, wręcz potępianą. Mimo iż działał wbrew uznawanym przez siebie wartościom, wniósł pozew o rozwód. Także żona podczas rozmowy na osobności zdawała się potwierdzać słowa męża w całości. Stwierdziła, że nie godzi się na terapię małżeńską, gdyż w jej przypadku uważa te środki za całkowicie bezprzedmiotowe. Nie chce rozwodu. Jej zdaniem mąż jest dobrym człowiekiem, opiekuńczym i kochającym, ale różnili się znacząco w kwestii praktyk religijnych.

Mediator nie znalazł ze stronami wspólnej płaszczyzny porozumienia. $\mathrm{W}$ jego ocenie pozwana rozmawiała wedle z góry przyjętych schematów myślowych i posługiwała się biblijnymi tekstami. Postępowanie mediacyjne niestety zakończyło się niepowodzeniem. Nie udało się uratować małżeństwa ani też polubownie ustalić warunków rozwodu bądź separacji.

W kolejnej sprawie - mediacja o podział majątku wspólnego po rozwodzie - były mąż złożył bardzo korzystną dla byłej żony i dla wspólnych dzieci propozycję podziału majątku wspólnego. Niestety podczas mediacji była żona nie skupiała się na przedmiocie sprawy, ale jakby oderwana od rzeczywistości stale wołała o sprawiedliwość i pomstę Bożą. Mimo obecności i dużego zaangażowania jej pełnomocnika nie podjęła z byłym mężem konstruktywnej rozmowy i w efekcie straciła mieszkanie, które mogłoby być domem dla niej i dzieci.

Zdaniem mediatorów zaangażowanych $\mathrm{w}$ przedmiotowe postępowania mediacyjne, prowadzenie tego rodzaju mediacji przez osobę duchowną lub uczestnictwo duchownego w roli komediatora mogłoby całkowicie zmienić ich przebieg i ostateczny rezultat. Autorytet duchownego, 
nieosądzanie stron przez duchownego, a nawet powołanie się na powagę Kościoła, mogłoby być czynnikiem umożliwiającym nawiązanie z pozwanymi konstruktywnego dialogu ${ }^{57}$.

\section{ZAKOŃCZENIE}

Podsumowując niniejsze opracowanie należy podkreślić, że niezależnie od posiadanej profesji każdy mediator, w tym również mediator będący duchownym, winien posiadać określone cechy/atrybuty predestynujące go do pełnienia tej funkcji. Są to m.in. umiejętność pozyskania zaufania stron, empatia, umiejętność słuchania i okazania zrozumienia, cierpliwość, wyzbycie się pokusy osądzania, umiejętność przekonywania i argumentacji zarówno co do treści, jak i formy przekazu, a przede wszystkim autorytet osobisty i społeczny.

Mediacja to praca z ludźmi w materii często delikatnej i osobistej. Rolą mediatora jest niejednokrotnie doprowadzenie do zmiany myślenia i postrzegania stron w obszarze konfliktu. Odwołanie się w toku postępowania mediacyjnego do paradygmatu uniwersalnych prawd moralnych oraz wspartych autorytetem duchownego wartości religijnych, może wzbudzić

57 Konflikty rodzinne i sprawy rozwodowe - szczególnie kiedy jedna ze stron zdecydowanie nie godzi się na rozwód - nie są jedynymi kategoriami sporów, gdzie rola duchownego mediatora wydaje się być ważna. Do innych kategorii takich sporów należą m.in.: konflikty o bardzo dużym ładunku negatywnych emocji (emocje odbierające zdolność krytycznej oceny i logicznego myślenia) - np. konflikty sąsiedzkie; konflikty w sprawach o podłożu religijnym bez względu na wyznanie; w sprawach, w których stroną jest Kościół lub osoba duchowna bez względu na wyznanie; w sporach zbiorowych; w sprawach, w których podjęcie bądź niepodjęcie leczenia dzieci jest warunkowane religią; w sprawach np. z art. 207 k.k. Uczestnicy postępowań mediacyjnych w sprawach karnych z art. 207 k.k. oraz w sprawach rodzinnych, uskarżają się na schematyzm i bezduszność działania wielu organizacji i stowarzyszeń zajmujących się rozwiązywaniem problemów rodzinnych, w tym sprawami przemocy w rodzinie. Rozmówcy informują, że oferowana pomoc najczęściej zakłada jedynie: zdefiniowanie (uświadomienie osobie pokrzywdzonej) faktu zaistnienia bądź rozmiaru przemocy; pomoc w przygotowaniu pozwu/aktu oskarżenia i materiału dowodowego; pomoc w trakcie postępowania karnego - wina i ukaranie sprawcy. Mniej istotna wydaje się być rola duchownych - mediatorów w sprawach gospodarczych czy administracyjnych, chociaż w szczególnych przypadkach nie można wykluczyć ich zaangażowania. 
u stron wolę pojednania i polubownego rozwiązania konfliktu, co jest podstawowym celem i pożądanym efektem mediacji. Bardzo pomocne i niedoceniane w procesie przeformatowania myślenia/postrzegania stron w procesie mediacji mogą być także umiejętności kaznodziejskie jako forma oddziaływania słowem o szczególnym zabarwieniu moralnym i emocjonalnym. Wydaje się zatem, że nową pożądaną wartością w polskim systemie mediacji mogłoby być uczestnictwo osób duchownych przygotowanych do zawodu mediatora i wpisanych na listę mediatorów stałych. Przede wszystkim jako komediatorzy mogliby służyć pomocą innym mediatorom, którym zlecono postępowania mediacyjne o szczególnym zabarwieniu. Wprowadzenie takiego rozwiązania wymagałoby rzetelnej informacji o możliwości skorzystania z pomocy mediatora - duchownego skierowanej do wszystkich mediatorów w danym okręgu. Za konieczne należałoby też uznać uprzednie przygotowanie duchownych do nowej dla nich funkcji, wypracowania zasad współpracy oraz oczywiście każdorazowej zgody stron sporu na udział duchownego $\mathrm{w}$ postępowaniu mediacyjnym.

$\mathrm{Z}$ jednej strony promowany obecnie w Polsce model mediacji zakłada rolę mediatora jako kreatora procesu porozumienia, stawiającego stronom pytania i zachęty skłaniające do samodzielnego poszukiwania rozwiązań. Z drugiej strony wielu uczestników postępowań mediacyjnych nie godzi się na uprzedmiotowienie ich problemu i sprowadzenie mediacji do odpowiedzi na pytanie kto jest winny. Oczekują od mediatora spojrzenia na ich spór także w wymiarze duchowym, tak by problem rozwiązać zgodnie z wyznawaną przez nich wiarą. Potrzebą czasu jest zatem również tworzenie ośrodków mediacyjnych w ramach struktur kościelnych, gdzie spory będą rozwiązywać duchowni i świeccy mediatorzy prezentujący określony system wartości.

BIBLIOGRAFIA

Alexander, Nadja. 2009. International and Comparative Mediation: Legal Perspectives. London: Kluwer Law International.

Barrett, Jerome, Joseph Barett. 2004. A history of alternative dispute resolution. The story of a Political, Cultural and Social Movement. San Francisco: JosseyBass A Wiley Imprint. 
Baruch Bush, Robert, Joseph Folger. 2012. „Mediation and Social Justice: Risks and Opportunities". Ohio State Journal on Dispute Resolution 27: 1-51.

Brown, Peter. 1993. Augustyn z Hippony. Warszawa: Państwowy Instytut Wydawniczy.

Burgoński, Piotr. 2009. „Patronat i mediacja duchownych w polityce”. W: Ile Kościoła $w$ polityce, ile polityki w Kościele, red. Piotr Burgoński, Sławomir Sowiński. Katowice: Księgarnia św. Jacka.

Colley, John. 2006. The Mediator's Handbook: Advanced Practice Guide for Civil Litigation. South Bend: NITA.

Dąbrowski, Marek. 2019. Mediacja w świetle przepisów kodeksu postępowania cywilnego. Lublin: Wydawnictwo KUL.

Giba, Matthews. 2000. „Religious dimensions of Mediation”. Fordham Urban Law Journal 27: 1695-1710.

Grocholewski, Zenon. 2002. „Służba miłości w działalności sądowej Kościoła". W: Veritati Salvificae Servire. Ksiegga pamiątkowa dedykowana ks. prof. zw. dr hab. Edwardowi Góreckiemu z okazji 70 rocznicy urodzin, red. Wiesław Wenz, 71-82. Wrocław: Papieski Wydział Teologiczny.

Kalisz Anna, Adam Zienkiewicz. 2014, Mediacja sądowa i pozasadowa. Zarys wykładu. Warszawa: Wolters Kluwer business.

Kordasiewicz, Stanisław. 2009. „Historyczna i międzynarodowa perspektywa mediacji”. W: Mediacje. Teoria i praktyka, red. Ewa Gmurzyńska, Rafał Morek, 31-50. Warszawa: Wolters Kluwer business.

Lowry, Randolph. 2004. „Evaluative Mediation”. W: Divorce and family mediation. Models, Techniques and Applications, red. Jay Folberg, Ann Milne, Peter Salem. New York: Guilford Press.

Mayer, Bernie. 2004. „Facilitative Mediation”. W: Divorce and family mediation. Models, Techniques and Applications, red. Jay Folberg, Ann Milne, Peter Salem. New York: Guilford Press.

Moore, Christopher. 2009. Mediacje. Praktyczne strategie rozwiazywania konfliktów. Warszawa: Wolters Kluwer Polska.

Morek, Rafał. 2009. „Cele i funkcje mediacji”. W: Mediacje. Teoria i praktyka, red. Ewa Gmurzyńska, Rafał Morek. Warszawa: Wolters Kluwer business.

Myrcha, Marian Alfons. 1948. Sady polubowne w prawie kanonicznym. Studium prawno-porównawcze. Lublin: Towarzystwo Naukowe KUL.

Nagy, Stanisław. 1982. „Dialog w Kościele”. Kościół i Prawo 2: 151-172.

Pawluk, Tadeusz. 2009. Prawo kanoniczne wedlug Kodeksu Jana Pawła II. T. 4: Doczesne dobra Kościoła. Sankcje w Kościele. Procesy. Olsztyn: Warmińskie Wydawnictwo Diecezjalne. 
Riskin, Leonard. 1996. „Understanding Mediators’ Orientations, Strategies, and Techniques: A Grid for the Perplexed". Harvard Negotiation Law Review 1: $7-51$.

Romanko, Agnieszka. 2016. Mediacja w sprawach administracyjnych w prawie kanonicznym i w prawie polskim. Lublin: Towarzystwo Naukowe KUL.

Roseman, Daniel. 2013. „Mediation in the Church: A Review of the Literature and the Key Elements of Mediation". Studia Canonica 47: 145-181.

Seul, Jeffrey. 1999-2000. „How Transformative is Transformative mediation? A Constructive-Development Assesments". Ohio State Journal on Dispute Resolution 15: 135-172.

Stitt, Alan. 2004. Mediation: A Practical Guide. London: Routledge-Cavendish.

Stulberg, Joseph. 1997. „Facilitative Versus Evaluative Mediator Orientations: Piercing the 'Grid' Lock”. Florida State University Law Review 24: 985-1005. Zarzycki, Zdzisław. 2007. „Mediacja osoby duchownej w postępowaniu o rozwód i separację". W: Funkcje publiczne związków wyznaniowych, red. Artur Mezglewski. Lublin: Wydawnictwo KUL.

Zienkiewicz, Adam. 2007. Studium mediacji. Od teorii ku praktyce. Warszawa: Difin. 